\begin{tabular}{l} 
RCCS \\
\hline Annual Review
\end{tabular}

\section{RCCS Annual Review}

A selection from the Portuguese journal Revista Crítica de Ciências Sociais

$3 \mid 2011$

Issue no. 3

\title{
Karl Polanyi and the New Economic Sociology: Notes on the Concept of (Dis)embeddedness
}

\section{Nuno Miguel Cardoso Machado}

Translator. João Paulo Moreira

\section{OpenEdition}

\section{Journals}

Electronic version

URL: http://journals.openedition.org/rccsar/309

DOI: $10.4000 /$ rccsar.309

ISSN: 1647-3175

\section{Publisher}

Centro de Estudos Sociais da Universidade de Coimbra

\section{Electronic reference}

Nuno Miguel Cardoso Machado, "Karl Polanyi and the New Economic Sociology: Notes on the Concept of (Dis)embeddedness », RCCS Annual Review [Online], 3 | 2011, Online since 01 October 2011 connection on 21 December 2020. URL : http://journals.openedition.org/rccsar/309 ; DOI : https:// doi.org/10.4000/rccsar.309 


\title{
Nuno Miguel Cardoso Machado
}

Research Centre in Economic and Organizational Sociology, School of Economics and Management (SOCIUsISEG), Technical University of Lisbon

\section{Karl Polanyi and the New Economic Sociology: Notes on the Concept of (Dis)embeddedness*}

\begin{abstract}
Within the context of the New Economic Sociology, Karl Polanyi is almost universally considered the "father" of the concept of embeddedness. However, this concept has been subject to selective appropriation by this discipline and its relationship to the remaining theoretical edifice constructed by Polanyi has been neglected. It is, in fact, possible to refer to the "great transformation" to which the concept of embeddedness has been subjected: whereas in Polanyi's work it is associated with the macro(economic) level and is used as evidence of the exceptional nature of the capitalist market economy - disembedded from society - in NES, it is normally associated with the meso (and even micro) level, on the assumption that all economies - including capitalist economies - are embedded.
\end{abstract}

Keywords: capitalism; market economy; embeddedness; Karl Polanyi; New Economic Sociology.

\section{Introduction}

Within the context of the social sciences, Karl Polanyi is usually viewed as the "father" of the concept of embeddedness. The New Economic Sociology is no exception to that, as it adopted the phrase as one of its central concepts (Krippner, 2001; Swedberg, 2006). However, the concept has been subject to selective appropriation by this discipline and its relationship to the remaining theoretical edifice constructed by Polanyi has been neglected. It is, in fact, possible to refer to the "great transformation" (Beckert, 2007) to which the concept of embeddedness has been subjected: whereas in Polanyi's work it is associated with the macro(economic) level and is used as evidence of the exceptional nature of the capitalist market economy - disembedded from society - in NES, it is normally associated with the meso (and even micro) level, on the assumption that all economies - including capitalist economies - are embedded. In other words, the economic actions of individuals are always part and parcel of networks of social relations.

Embeddedness, ${ }^{1}$ for Polanyi, means that the economy is immersed in social relations, i.e., it cannot be a separate, autonomous sphere vis-a-vis society as a whole. One must point out,

\footnotetext{
* Article published in RCCS 90 (September 2010).

${ }^{1}$ The concept had already been used by Thurnwald, who was one of Polanyi's major influences in the field of economic anthropology. So Thurnwald must have been the inspiration for Polanyi's adoption of the concept of embeddedness (Beckert, 2007: 7). Block (cf. 2000: 7), on the other hand, suggests that Polanyi got his
} 
however, that the author did not intend to create a new concept, nor did he seem in the least concerned with giving it an explicit definition. Perhaps that is the reason why the concept of (dis)embeddedness has been the object of a number of contradictory interpretations. Still, the best way to understand the true meaning and the implications of the concept is to try and grasp it in close interconnection with Polanyi's entire theoretical and conceptual edifice, which is to say, by capturing its role, function, relationship and place in the author's thinking. Besides, trying to understand the concept solely from a number of disparate statements made by the author - namely from its explicit uses in The Great Transformation - may prove a pointless, misleading endeavor rather than an enlightening one (as we will see to be the case in the context of the New Economic Sociology).

I have shown elsewhere the unique character of the modern capitalist market economy as viewed by Polanyi (Machado, 2009). I will now summarize some of the main concepts behind it. In order to fully understand Polanyi's work and thought, one has to start by analyzing the distinction he makes between the substantive and the formal meaning of economy. The formalist approach is based on an ontological scarcity of the means for providing to human needs, and takes as its object of analysis the discrete ("rational") individual who seeks to maximize his gains, i.e., it stays within the predicates of homo economicus. According to Polanyi, the formalist schema - based on the neoclassical model of economic theory - can only be applied to the study of modern capitalist economies, where price-making markets play a crucial role. ${ }^{2}$ The substantivist approach, on the other hand, in its effort to study the role of the economy within society, deals with the institutional forms taken by the process of satisfaction of human needs in different societies, both past and present, its main concern being sufficiency rather than efficiency.

inspiration from a word used in mining: while studying British economic history in preparation for The Great Transformation, he most certainly read extensively on the history of the technologies used in the British mining industry, whose job it was to extract "embedded" coal from the rocky walls of mines.

${ }^{2}$ One scholar pointedly asks whether, according to Polanyi, formalist theory may be entirely applied to the study of the capitalist market economy. While it is true that Polanyi says that "even in regard to the market system itself, the market as the sole frame of reference is somewhat out of date" (Polanyi, 1968a: 174), he also writes that "once a human being was circumscribed as an 'individual in the market', the [formalist] proposition [...] was easy to substantiate" (Polanyi, 1977c: 29). The capitalist economy confronts individuals with choices brought about by a shortage of means; therefore it can be analyzed by applying those methods based on the formal meaning of the economy. As long as this economic system obtains, the formal meaning and the substantive meaning will coincide for all practical purposes (Polanyi, 1968a: 141; Polanyi, 1977a: 10-11), because the institutional arrangements ensuring human subsistence only reflect the arrangements of formalism. This debate goes well beyond the scope of the present paper, but we can (safely) assume that Polanyi grants the formalist schema some degree of explanatory power only when it applies to the modern capitalist economy. 
Thus, according to the author, one must acknowledge the relevance of the substantive definition, which views the economy as an instituted process of interaction between man and his natural and social environment. Such a process results in an ongoing - and, in this case, universal - supply of material means to satisfy human needs, and is the foundation of the method envisaged by Polanyi: institutional analysis. The economy may of course be instituted in different ways from one society to another, and so Polanyi identifies three major patterns, or so-called forms of integration - reciprocity, redistribution and (market) exchange - which combine to give the economy its unity and stability, that is, the interdependence and recurrence of its parts. ${ }^{3}$

According to Polanyi's classification, primitive or tribal societies are characterized by reciprocity and also, to a certain extent, by redistribution. Archaic societies, in turn, are predominantly redistributive, although there may be room for some exchange. One has to keep in mind, however, that the system of self-regulating markets as the dominant form of integration is only to be found in modern societies. We may therefore conclude that Polanyi's attempt to formalize a globally relevant comparative economics and the importance of the concept of embeddedness itself are precisely the result of his need to emphatically underscore the differences between the various social and economic systems, namely between capitalism and every single society that came before it. Karl Polanyi's thinking is driven by the wish to highlight the absolute exceptionalism of the market economy ${ }^{4}$ in the history of humankind. The embeddedness/disembeddedness condition must be understood, first and foremost, in the context of that distinction.

\footnotetext{
${ }^{3}$ For an analysis of the forms of integration proposed by Polanyi as well as of their empirical use in the study on Dahomey and the Slave Trade, see Machado (2009: 54-68; 79-89). Briefly put, reciprocity denotes movements between correlative points of symmetrical groupings, which means that it presupposes the existence of symmetry as institutional background. What we have is a system of gifts and counter-gifts, a continuous give and take (such as Malinowski's Kula ring). Redistribution describes appropriative movements toward a center and back (that is, away from the center); in institutional terms, it depends on the presence of some degree of centricity within the group (e.g. ancient empires - such as the Egyptian or Roman empire, etc.; Dahomey). As to exchange, it refers to the "vice-versa" movements occurring among "agents" under a market system; so in order to generate integration it requires a system of price making. Therefore (market) exchange consists of a two-way movement of goods between people, aiming at obtaining gains for the parties involved.

${ }^{4}$ Let us clarify the concept of capitalism, which Polanyi defines as an interconnected system of price-making markets, i.e., as a market economy (regulated by the mechanism of supply and demand).
} 


\section{Karl Polanyi: The disembeddedness of the capitalist economy}

In fact, some authors tend to complain that the concept of embeddedness is used but twice throughout The Great Transformation. However, a reader imbued with the right perspective - that is, one who has made a thorough study and analysis of Polanyi's thinking in its entirety - will be able to capture the full meaning of the concept:

The market pattern, [...] being related to a peculiar motive of its own, the motive of truck or barter, is capable of creating a specific institution, namely, the market. Ultimately, that is why the control of the economic system by the market is of overwhelming consequence to the whole organization of society: it means no less than the running of society as an adjunct to the market. Instead of economy being embedded in social relations, social relations are embedded in the economic system. The vital importance of the economic factor to the existence of society precludes any other result. For once the economic system is organized in separate institutions, based on specific motives and conferring a special status, society must be shaped in such a manner as to allow that system to function according to its own laws. This is the meaning of the familiar assertion that a market economy can function only in a market society. (Polanyi, 2000: 77, emphasis added)

In the vast ancient systems of redistribution, acts of barter as well as local markets were a usual, but no more than a subordinate trait. The same is true where reciprocity rules; acts of barter are here usually embedded in long-range relations implying trust and confidence, a situation which tends to obliterate the bilateral character of the transaction. (Polanyi, 2000: 81-82, emphasis added)

These quotes are perfect illustrations of the basic fact that throughout the book Polanyi clearly contrasts capitalist society with past communities, where the economy, framed by other institutional patterns, did not exist apart from society at large, nor was it even, most of the times, an identifiable, noticeable entity, since it was totally submerged in social relations. On the contrary, under capitalism the economy became disembedded (i.e., loose or, as it were, autonomized), leaving society at the mercy of a blind mechanism - the self-regulating market - that controls and overpowers it. Thus in practice the embeddedness of the economy is tantamount to the absence of a system of price-making markets.

Besides, and more important, only a perfunctory analysis would settle for an explicit, literal search for the concept's meaning. It seems obvious that it would be too reductive to limit one's inquiry to the search for or the counting of how many times the word "(dis)embeddedness" occurs. It should also be pointed out that throughout his work Polanyi expresses similar ideas without exactly resorting to that particular word. As proof of that, let's look at two revealing, if commonly overlooked, examples from The Great Transformation: 
The outstanding discovery of recent historical and anthropological research is that man's economy, as a rule, is submerged in his social relationships. He does not act so as to safeguard his individual interest in the possession of material goods; he acts so as to safeguard his social standing, his social claims, his social assets. He values material goods only in so far as they serve this end. Neither the process of production nor that of distribution is linked to specific economic interests attached to the possession of goods; but every single step in that process is geared to a number of social interests which eventually ensure that the required step be taken. These interests will be very different in a small hunting or fishing community from those in a vast despotic society, but in either case the economic system will be run on noneconomic motives. (Polanyi, 2000: 65, emphasis added)

A self-regulating market demands nothing less than the institutional separation of society into an economic and a political sphere. Such a dichotomy is, in effect, merely the restatement, from the point of view of society as a whole, of the existence of a self-regulating market. It might be argued that the separateness of the two spheres obtains in every type of society at all times. Such an inference, however, would be based on a fallacy. True, no society can exist without a system of some kind which ensures order in the production and distribution of goods. But that does not imply the existence of separate economic institutions; normally, the economic order is merely a function of the social order. Neither under tribal nor under feudal nor under mercantile conditions was there, as we saw, a separate economic system in society. Nineteenth-century society, in which economic activity was isolated and imputed to a distinctive economic motive, was a singular departure. (Polanyi, 2000: 92-93, emphasis added)

One should keep in mind that state intervention or regulation does not mean that the economy is embedded. In Polanyi one can find two different types of regulation, which do not belie the empirical existence of a disembedded economy, but are, on the contrary, intimately connected with its historical implementation: a) the establishment of the preconditions for a market economy to come into existence (enclosures, the establishment of a "free" labor market, etc.); b) protective measures against disembeddedness, primarily to slow down the pace of change brought about by the transformation into a market economy (labor laws, Speenhamland, etc.).

State regulation can only provide the framework for the (self-regulated) market to operate, but it cannot dictate how it operates (which would be illogical). According to Polanyi, there is a set of assumptions regarding the state and its policies, and all measures or policies that interfere with the workings of the market are to be avoided. Prices, supply and demand - none of these should be stipulated or regulated; the only valid policies and measures will be those aimed at ensuring that the market regulates itself, thus creating the conditions for it to be the sole organizing power in the economic sphere (Polanyi, 2000: 9091; Stanfield, 1986: 111). For Polanyi, the existence of the state - the (democratic) "liberal" state - is not synonymous with embeddedness, just as social protection measures are not 
synonymous with (re)embeddedness. Conversely, separation between politics and the economy is the very proof of disembeddedness.

Once we understand the importance of the concept of (dis)embeddedness as something that is intimately associated with Polanyi's comparative analysis of the market economy and past economies, its central role in Polanyian thinking will become evident. If, on the other hand, we are mostly intent on counting the exact number of times the word "disembeddedness" is used in his work, then we will - fallaciously - conclude that the concept had little relevance for Polanyi in the first place, and the leitmotiv of his entire inquiry will be lost on us. Furthermore, we will probably downplay its meaning and will tend to dismiss it as mere misunderstanding, selectively appropriating what after all seems more important to ourselves: the very term "(dis)embeddedness," clearly endowed with a different meaning. I believe this is what happened with NES. But more on this later.

Still, let it be noticed that the word "(dis)embeddedness" is not used that sparingly by Polanyi. ${ }^{5}$ Notwithstanding, most authors just mention the two occurrences in Polanyi's magnum opus, failing to read the rest of his work (as is the case with Barber, 1995; Ghezzi and Mingione, 2007; Granovetter, 1985. Swedberg [1997, 2004] does not make a single reference to Polanyi in his bibliography). One has to go to "Aristotle Discovers the Economy" (Polanyi, 1957), a paper rarely mentioned in the literature, to find what is perhaps Polanyi's clearest and most systematic use of the concept of embeddedness. Let us look at a long but telling - actually the most telling - quote regarding the concept of dis(embeddedness):

The conceptual tool with which to tackle this transition from namelessness to a separate existence [of the economy] we submit, is the distinction between the embedded and the disembedded condition of the economy in relation to society. The disembedded economy of the nineteenth century stood apart from the rest of society, more especially from the political and governmental system. In a market economy the production and distribution of material goods in principle is carried on through a self-regulating system of price-making markets. It is governed by laws of its own, the so-called laws of supply and demand, and motivated by fear of hunger and hope of gain. Not blood-tie, legal compulsion, religious obligation, fealty or magic creates the sociological situations which make individuals partake in economic life but specifically economic institutions such as private enterprise and the wage system.

[...] Under a market system men's livelihood is secured by way of institutions that are activated by economic motives, and governed by laws which are specifically economic. The vast comprehensive mechanism of the economy can be conceived of working without the conscious intervention of human authority, state or government.

This, then, is the nineteenth century version of an independent economic sphere in society. It is motivationally distinct, for it receives its impulse from the urge of monetary gain. It is institutionally separated from the political and governmental center. It attains to an autonomy

\footnotetext{
${ }^{5}$ Polanyi, 1966: 60, 81; 1968a: 141, 148; 1968b: 70; 1977a: 9; 1977b: 53; Polanyi et al., 1968: 118-119.
} 
that invests it with laws of its own. In it we possess that extreme case of a disembedded economy which takes its start from the widespread use of money as a means of exchange. (Polanyi, 1957: 67-68, my emphasis)

It seems obvious that, for Polanyi, the market economy was indeed disembedded. ${ }^{6}$ We can say that the "market economy thus created a new type of society. The economic or productive system was here entrusted to a self-acting device. An institutional mechanism controlled human beings in their everyday activities as well as the resources of nature" (Polanyi, 1968b: 62). And the author further contrasts capitalist society with primitive and archaic societies:

As long as these latter forms of integration [i.e., reciprocity and redistribution] prevail, no concept of an economy need arise. The elements of the economy are here embedded in noneconomic institutions, the economic process itself being instituted through kinship, marriage, age-groups, secret societies, totemic associations, and public solemnities. The term 'economic life' would here have no obvious meaning. [...] [T] here existed, as a rule, no term to designate the concept of economic. [...] This concept was [simply] absent. [...] The prime reason for the absence of any concept of the economy is the difficulty of identifying the economic process under conditions where it is embedded in noneconomic institutions. (Polanyi, 1957: 70-71)

For this reason, in societies of the past the economy was not only embedded in society but most of the times those societies possessed no notion, concept or awareness of an economic sphere that was clearly identifiable or recognizable as such by their members.

\section{The New Economic Sociology: "All economies are embedded"}

\subsection{NES and the concept of embeddedness}

According to Swedberg, "Economic sociology is a term that was rarely heard a decade ago but which has become quite popular again. Today sociology departments get ranked according to their prominence in this field, and a respectable number of articles and books

\footnotetext{
${ }^{6}$ One scholar challenges the validity of this (long) quote as representative of Polanyi's work. Again, let us go back to Polanyi: with capitalism, "an 'economic sphere' came into existence that was sharply delimited from other institutions in society. Since no human aggregation can survive without a functioning productive apparatus, its embodiment in a distinct and separate sphere had the effect of making the 'rest' of society dependent upon that sphere. [...] As a result, the market mechanism became determinative for the life of the body social. No wonder that the emergent human aggregation was an 'economic' society to a degree previously never even approximated" (Polanyi, 1968b: 63). According to Polanyi, equating economic phenomena with market phenomena almost became a practical requisite after the emergence of the new society and its way of life, in the wake of the early stages of the Industrial Revolution (Polanyi, 1977a: 9). Thus "what we have here called the economistic fallacy was an error mainly from the theoretical angle. For all practical purposes, the economy did now consist of markets, and the market did envelop society" (Polanyi, 1977a: 9). See also, for instance, Polanyi, 1968b: 70; 1977a: 9; 1977b: 53. Polanyi-Levitt (cf. 2003: 2-3) also underscores the centrality of the disembeddedness of the capitalist economy for Polanyi.
} 
that label themselves 'economic sociology' appear every year" (2006: 2). Graça, in turn, rightly points out that "in the area of social theory over the last decades, the emergence of the 'new economic sociology', namely in connection with such authors as Mark Granovetter and Richard Swedberg, ${ }^{7}$ is a fundamentally relevant and meaningful fact" (2005: 111).

One of the most important developments in the social sciences over the last decades has been the attempt to fill the void left by the failure of mainstream economic science with regard to the inquiry into economic institutions. This is precisely the context within which the emergence of the New Economic Sociology has to be understood (Swedberg, 1997: 161). However, as Graça once again puts it,

NES dared to refute, if only in part, some of the assumptions and methods of academic economics. At the same time, however, it hastened to delimit the scope of the refutation, and again and again tended to retrace its steps and revert to the traditional, self-legitimizing allegation that there are a number of points of view or analytical angles and that its own view is just one among several, in juxtaposition with - rather than in opposition to - that of economics. ${ }^{8}$ (2005: 111, emphasis added)

The new discipline has its roots in a number of studies dating from the early 1980s. But if one had to pick a particular year to mark its real "birth" then the choice would be 1985 , the year of the publication, by Granovetter, of what would become the most popular article of contemporary economic sociology, "Economic Action and Social Structure: The Problem of Embeddedness" (cf. Swedberg, 1997: 161-162). It should be stressed, however, that contrary to modern economics, economic sociology still lacks a central core of ideas and concepts resulting from a process of shaping, mixing and refining over a considerable period of time. Instead, economic sociology - very much like what happens in the field of sociology consists of a set of competing perspectives, some more coherent than others (Swedberg, 2006: 3).

In spite of that, some central concepts have gained prominence. Among these is the concept of embeddedness and the related concept of (social) networks. Swedberg goes as far as stating that "the most famous concept in today's economic sociology is by far that of

\footnotetext{
${ }^{7}$ Among NES's top names, besides Swedberg and Granovetter, mention should be made of Patrik Aspers, Jens Beckert, Ronald Burt, Michel Callon, Bruce Carruthers, Neil Fligstein, Philippe Steiner and Viviana Zelizer (cf. Swedberg, 2006: 20-21). It should be noted that NES has been a largely North American phenomenon, albeit with a small number of researchers in several European countries (Swedberg, 1997: 164).

${ }^{8}$ Beckert expresses a similar opinion: "economic sociology finds a unifying denominator in its critique of [...] the notion of homo economicus acting in a world with full information, independent decision making, polypolistic competition, transitivity, and fixed preferences. [...] [Nonetheless,] new economic sociology does not put enough emphasis on proposing an alternative to rational actor theory" (2003: 769-770, emphasis added).
} 
embeddedness" (2006: 3). And Krippner adds, "The notion of embeddedness enjoys a privileged - and as of yet, largely unchallenged - position as the central organizing principle of economic sociology. [...] [In fact,] the term has gained widespread acceptance as representing the core unifying themes of the subfield" (Krippner, 2001: 775). The centrality of embeddedness for the 'new economic sociology' (from the mid-1980s to the present) is unquestionable (Swedberg, 2006: 3). ${ }^{9}$

Swedberg observes that Granovetter (1985) introduced a concept of embeddedness that is not only different from, but also more analytically useful than, Polanyi's. First of all, he challenged the political dimension of Polanyi's ideas by arguing that pre-capitalist economies were as embedded as the capitalist economy itself, given that both of them are social, in the sense of being embedded in the social structure. Second, he gave the concept of embeddedness greater analytical precision by insisting that all economic actions are embedded in networks of social relations. ${ }^{10}$ So in truth there is no such thing as a general embeddedness of the economy; all economic actions have an interpersonal manifestation, which, thanks to network theory, can now be defined with precision (Swedberg, 2006: 4).

Thus, what makes embeddedness an especially useful concept, according to many economic sociologists, are its links with network theory. This type of method, which became very popular among today's (new) economic sociology, provides the analyst with a metric for examining social interactions, including economic ones. Because it relies heavily on visual representation, network theory gives the researcher an instrument whereby complex social relations can be quickly rendered and interpreted (Swedberg, 2006: 4-5).

We may conclude that the advent of NES was associated with a set of key ideas: all economic actions are "embedded"; markets can be conceptualized as "social structures"; and economic actions comprise both a rational component and a socio-cultural component (Swedberg, 2004: 317). According to Swedberg,

Economic sociology, as it exists today, can be described as a well established subfield in sociology with a distinct identity of its own [...]. It has been strongly felt, from the 1980s and

\footnotetext{
${ }^{9}$ The concept of embeddedness has been used in other disciplines as well. In addition to economic anthropology (especially as a result of Polanyi's influence over the substantivist camp), economic geography (Hess, 2004), archaeology (Cumberpatch, 2001), and history (Knowles, 2000; Knowles and Owen, 2008) also deserve mention.

${ }^{10}$ Elsewhere Swedberg also makes it clear that while Polanyi proposed the concept of embeddedness to highlight the fact that in pre-capitalist times the economy was an organic part of society, Granovetter's intent when he uses the concept is almost the opposite: to show that economic actions are truly social actions within capitalist society (Swedberg, 1997: 165).
} 
onwards, that it was important for economic sociology to have its own profile, which could set it apart especially from mainstream neoclassical economics but also from other approaches to economics, such as socio-economics and 'old' institutionalist economics. (Swedberg, 2004: 325, emphasis added)

What is interesting about this quote is that, despite NES' claim to be - at least to a certain degree - part of Polanyi's legacy, it also felt the need to move way from the "old" institutionalist economy. But it is a well known fact that Polanyi tends to be linked with that very same "school," in the wake of authors like Veblen, Commons, etc. (Stanfield, 1986).

\subsection{Literature overview}

It is fair to say that the classical position of NES is still Granovetter's (1985), which closely links the concept of (dis)embeddedness to that of social networks and therefore to a "meso" (and often even a "micro") level, as opposed to a "macro" perspective. This position, in short, argues that "[economic] behavior is closely embedded in networks of interpersonal relations" (Granovetter, 1985: 504).

According to Granovetter, one of the central concerns of social theory has been to understand the extent to which behavior and institutions are impacted by social relations. Thus, in "Economic Action and Social Structure" he attempts to analyze the degree to which, in modern industrial society, economic action is embedded in structures of social relations. Common neoclassical approaches offer an "undersocialized" explanation for such action, that is, one that is based on the atomized actor. Reformist economists seeking to bring social structure back to the analysis, on the other hand, do so in an "oversocialized" manner. Both explanations are paradoxically similar in their neglect of the ongoing structures of social relations (Granovetter, 1985: 481-2).

It follows that "a fruitful analysis of human action requires us to avoid the atomization implicit in the theoretical of under- and oversocialized conceptions." The reason is that

Actors do not behave or decide as atoms outside a social context, nor do they adhere slavishly to a script written for them by the particular intersection of social categories that they happen to occupy. Their attempts at purposive action are instead embedded in concrete, ongoing systems of social relations. (Granovetter, 1985: 487, emphasis added)

As to the substantivists vs. formalists debate (Machado, 2009: 15-54), Granovetter tells us that his

view diverges from both schools of thought. I assert that the level of embeddedness of economic behavior is lower in nonmarket societies than is claimed by substantivists and 
development theorists, and it has changed less with 'modernization' than they believe; but I argue also that this level has always been and continues to be more substantial than is allowed by formalists and economists. (Granovetter, 1985: 482-483)

Note, however, that Granovetter does not attempt to approach these issues with nonmarket societies in mind. Instead, he formulates a theory of the concept of embeddedness whose importance is exemplified by a problem posed by modern society: which transactions, in modern capitalist society, occur in the marketplace and which are subsumed within hierarchically organized companies (Granovetter, 1985: 493). But as he admits in the end,

I have had little to say about what broad historical or macrostructural circumstances have led systems to display the social-structural characteristics they have, so I make no claims for this analysis to answer large-scale questions about the nature of modern society or the sources of economic and political change. (Granovetter, 1985: 506, emphasis added)

Nonetheless, he believes that the argument in favor of embeddedness shows "not only that there is a place for sociologists in the study of economic life but that their perspective is urgently required there" (Granovetter, 1985: 507).

In a particularly enlightening comment (Krippner et al., 2004), Granovetter admits that over the past few years he has rarely used the concept of embeddedness in his writings "because it has become almost meaningless, stretched to mean almost anything, so that it therefore means nothing" (Krippner et al., 2004: 113). This particular piece becomes even more interesting when Granovetter sheds light on the genesis of his seminal paper. According to him, he used the concept of embeddedness in his 1985 paper in a narrower and somewhat different sense than the one originally proposed by Polanyi:

[T] he reason is that I wasn't trying to borrow the term from Polanyi, or to re-appropriate it or reintroduce it. [...] I have looked back in my old notebooks and found that I used the term 'embeddedness' in some of my very early notes, before I ever read Polanyi. And I used it in the way that I use it in the 1985 paper to mean the way social and economic activities are mixed up with networks of social relations. [...] at some later time I did read Polanyi. I read particularly "The Economy as Instituted Process." It was not until much later that I really carefully read The Great Transformation. (Krippner et al., 2004: 113)

To further quote Granovetter: "when I came around to writing the paper on embeddedness, I had, in fact, forgotten about Polanyi, and was not thinking about him when I wrote that paper" (Krippner et al., 2004: 114). After the draft version began circulating, the author was hailed by one of its readers for bringing back Polanyi's concept of embeddedness. In truth, however, 
I read the letter and I thought 'oh my gosh, I'd completely forgotten that Polanyi uses it [the concept], and uses in a somewhat different way.' So I did say a little bit in the paper on embeddedness about Polanyi, but the main thing I was trying to do in that little section was to distance myself from his use of embeddedness. (Krippner et al., 2004: 114)

I think the two last quotes speak for themselves. It is not without irony that the paper most widely mentioned as deserving of laying claim to a "Polanyian" legacy in the discipline of (new) economic sociology made no allusion whatsoever to Polanyi's work.

In NES it is commonly understood - and in a way that understanding became the premise for most of the research conducted within the discipline - that Granovetter's main concern in his seminal paper was the claim that analysis of social networks is the main or sole goal of the sociological endeavor (see for example Swedberg, 1997: 165). But Granovetter believes he was explicit regarding his own research when he made the strategic decision "to look at social networks as an intermediate level between lower levels and higher levels" (Krippner et al., 2004: 114). While admitting he may not have made his point clearly enough in that paper, the author argues that it is obvious that "you can't just analyse social networks, you also have to analyse institutions and culture and politics and all of the micro and macro elements, of which the 'meso-level' of social networks is in the middle" (Krippner et al., 2004: 114). Granovetter then proceeds to conclude that "if I had known it would be an influential paper I would have taken more care to say that there's more to life than [just] the structure of social networks" (Krippner et al., 2004: 115).

Barber, in turn, argues that "a better general theoretical understanding of embeddedness should be of wide usefulness in contemporary sociological analysis" (1995: 388). The central (cultural) concept to which embeddedness is related is that of "market." In fact, the history of the concept of embeddedness may be viewed as a long struggle to overcome what Barber calls "the absolutization of the market" (Barber, 1995: 388).

For Barber, market exchange is interdependent with a set of social, structural and cultural variables that form modern socials systems, to wit, equity, efficiency, universalism, specific property rules, etc. (Barber, 1995: 399). So, while Polanyi's analysis regarding the three forms of integration - reciprocity, redistribution and exchange - may be valuable, it becomes less so and even misleading when it deals with the issue of their different "levels" of embeddedness:

Polanyi describes the market as 'disembedded', the other two types of economic exchange as [being] more 'embedded' in the other social-structural and cultural-structural elements of 
society. [But,] as should now be clear, after what has been said about the connection of all three types of economic exchange with some set of social structural and cultural elements in the social systems in which they occur, our strong proposition, contrary to Polanyi's, is that all economies are inescapably embedded. (Barber, 1995: 400)

Therefore,

While the modern market system may appear to be more differentiated from other social system structures, somewhat more concretely separate, this image diverts attention from the basic fact of its multiple and complex interdependence with the rest of the social system. Calling the market 'disembedded' leads analytic attention away from just what this interdependence is [in reality]. (Barber, 1995: 400)

Barber even expresses disappointment with the fact that Polanyi did not explicitly conceive of a social system in which the economy was always a part of - and just one part among the variously different and interdependent (social, structural and cultural) parts that make up the essence of any particular social system (Barber, 1995: 401).

According to Barber, Granovetter's paper had the great merit of precisely emphasizing how every economic action is embedded in non-economic social relations. But he still has a few criticisms of the paper, the most salient being that Granovetter's analysis "shows no understanding of the importance of the larger social systems in which all economies are located" (Barber, 1995: 406). Still according to Barber,

Granovetter says that economic behavior is embedded in "social structure," and for him social structure apparently means only networks of interpersonal relations. There is no specification of the several different social and cultural structures that make up the larger social system. Where have the social structures of kinship, stratification, gender, age, the economy, the polity, organizations, education, and communications disappeared to? (ibid.: 406-407)

Barber's main thesis, in short, is that the best way for the concept of embeddedness to evolve would be to acknowledge that all types of economy are embedded in complex, more comprehensive social systems. On the other hand, the socio-structural, socio-cultural and personality components of such systems ought to be specified. Finally, their interrelations with the economic systems - which are but a part of the social system - should be better understood and, consequently, either stabilized or transformed (Barber, 1995: 407-408).

Block's (cf. 2000; 2003) is perhaps the most distinctive perspective within NES, even if he also ends up concluding that all economies are embedded. First of all it must be said that for him the concept is imbued with the meaning that was first given to it by Polanyi, i.e., as referring to a "macro" perspective, to a comprehensive understanding of the economic 
system as a whole. Nevertheless, his conclusions are different from Polanyi's with regard to the disembedded nature of capitalism.

According to Block, the modern market economy has a latent tendency toward disembeddedness, which means that, empirically speaking, the economy comes very close to being disembedded. However, "full-fledged" disembeddedness is simply impossible, in that it would destroy society at once. Because of the need for state intervention and for social protection, particularly in what concerns the regulation of fictitious commodities, the economy, even the capitalist economy, "is always embedded." Thus, in Block's view a selfregulated economy is nothing but a (stark) utopia. Even if in an ambiguous way, Karl Polanyi himself affirms the practical impossibility of total disembeddedness. The ambiguity arises from the tension between the Polanyi that was influenced by a Marxist theoretical framework (until the 1930s) and a later Polanyi, one involved with the concepts and positions he himself had shaped while writing The Great Transformation, and which often ran counter to those of the earlier frame of reference (Block, 2003). In short, capitalism is moving toward a state of disembeddedness and in fact comes very close to it, but it will never attain that state without causing society to collapse.

At various times Polanyi seems indeed to confirm Block's claims, as when he states that "the idea of a self-adjusting market implied a stark utopia" (Polanyi, 2000: 18). But it must be noted that he wrote these words in The Great Transformation when he believed to be witnessing the collapse, at long last, of "19th century civilization," that is, the demise of a society based on the self-regulated market (Polanyi, 2000: 17-18). Thus, the self-regulated market had proved its practical incapacity to organize the life of human societies. "Utopia" (dystopia), which was then being disproved by events, resulted from the empirical failure of the capitalist system (which in fact, as we now know, did not occur): not from the fact that no self-regulated market had ever existed, but from the fact that its short existence for a (relatively) brief period of time had led humankind to the biggest crisis in its history. For Polanyi, it was the (real) historical events that invalidated the alleged virtues of the market, thus signaling the beginning of a "great transformation" characterized by the onset of other economic experiments (socialism, fascism and the New Deal). The self-regulated market utopia does not derive from its practical impossibility, but rather from the belief that it could operate indefinitely without ever causing deeply harmful effects to both Man and nature. 
"Industrial civilization will continue to exist when the utopian experiment of a self-regulating market will be no more than a memory" (Polanyi, 2000: 290).

Krippner, who is well aware of the differences between the concept of embeddedness as it was first proposed by Polanyi and the one envisaged by Granovetter, wrote a thorough review of the two visions (Krippner and Alvarez, 2007). Although acknowledging the merit in Granovetter's claim that all economies are embedded, Krippner is critical of the fact that the NES camp has evolved and shaped itself almost exclusively around that concept (Krippner, 2001: 775-776).

What happens is that, to an even greater degree than most of the subfields of sociology, the (new) economic sociology is built upon a key idea: the concept of embeddedness. Hence Krippner's argument that the notion of embeddedness deflected attention from other important theoretical problems. She specifically suggests that the relative neglect of the market concept in economic sociology is a consequence of the way in which the notion of embeddedness was formulated. Paradoxically, the basic intuition - in itself an extremely useful one - that markets are socially embedded led economic sociologists to take the market for granted. As a consequence, economic sociology did not fare much better than economics with respect to developing the market concept as a theoretical subject in its own right, which caused an interesting case of arrested development of the market concept within the discipline (Krippner, 2001: 776; Krippner et al., 2004: 111-112).

In attempting to steer a middle course between the undersocialized and the oversocialized views of action, Granovetter ended up adopting the idea that they both share: the separateness of society and the economy. This problem manifests itself in a curious symmetry within the discipline: researchers either study economic processes in social terms - thereby turning their backs on the market sphere - or they study the market as a theoretical entity in its own right, in which case they excise its entire social content (Krippner et al., 2004: 112-113).

In view of this, as long as the market is not entirely appropriated as a social object, a tension will continue to exist between marketless conceptions of the social on one hand, and on the other hand conceptions of the economy from which all social traces have been suppressed (Krippner et al., 2004: 113).

Beckert (2007) offers a fine synthesis of how the concept of embeddedness has evolved. As mentioned above, he points out that when the concept was borrowed from Polanyi and 
subsequently adapted, it underwent a "great transformation," losing some elements of the original notion in the process while gaining a few others (Beckert, 2007: 7). Beckert highlights other aspects we have already covered here also: the irony surrounding the concept, coupled with the fact that Granovetter did not have Polanyi's work in mind when he wrote his paper (Beckert, 2007: 9-10); the fact that the concept introduced by Granovetter is intimately associated with that of social networks (Beckert, 2007: 8-9); and the dominant position of the latter interpretation within NES (Beckert, 2007: 9).

Beckert is critical of Granovetter's position and of network analysis, on the grounds that

This is a limited perspective because an exclusive focus on the structure of social relations leads to a neglect of the social content underlying the observed structure. By not taking attributes of actors and institutional rules into account, network analysis fails to explain how the social structure of markets emerges and why networks are structured the way they are. (Beckert, 2007: 9)

Furthermore, he argues that the concept of embeddedness is not the best sociological approach to the economy. Therefore,

one can question whether sociology should start from this notion as its entry point into the field of the economy. My position is that 'embeddedness' characterizes a general answer to specific problems without identifying the underlying problems themselves. By starting from the embeddedness of economic action we are putting the cart before the horse. The first proper step would be to identify the problems that can actually be solved by an approach focusing on the embeddedness of economic action. I suggest that we identify these problems and make them the analytical starting point of economic sociology. (Beckert, 2007: 10-11)

NES should then take as its starting point the "three coordination problems" that actors are faced with in market exchanges: the value problem, the competition problem and the cooperation problem (Beckert, 2007: 11-15).

For Beckert, the attraction exerted by Polanyi upon NES arises from the fact that his social theory does not entail a "linear concept of development." In other words, embeddedness is not a feature separating pre-modern from modern economies. Based on the notion of a "double movement," social change is conceptualized as a dynamic process of oscillation between embeddedness, disembeddedness, and re-embeddedness. Therefore, all economies are (in some way) embedded (Beckert, 2007: 19).

From the preceding analysis it should be obvious that I cannot agree with this interpretation, which - as will presently be shown - proves problematic for Beckert himself. In brief, what we have is the exact opposite of what Beckert envisions: Polanyi couldn't be more explicit when he stated that until very recently - before the emergence of the 
capitalist market economy - all economies were embedded in society. Therefore the economy's embeddedness /defensive counter-response / need for re-embeddedness is not something that historically has been there all along but rather quite a recent "problem." By failing to recognize - alongside other NES scholars - that the specificity of the capitalist economy lies precisely in its being disembedded and by claiming that "all economies are embedded," Beckert finally finds himself stuck in a problem for which there is no apparent solution. Here are his own words:

However, 'embeddedness' does not provide a theoretical perspective informing us about the specific characteristics of the embeddedness of modern capitalist economies. The strong emphasis on similarities of economic systems across time and space, based on the notion of embeddedness, impedes the development of conceptual tools to address differences between economic configurations and, in particular, the specificity of the organization of modern capitalist economies. (Beckert, 2007: 19, emphasis added)

These few lines actually summarize my critique of NES's understanding of the concept of embeddedness. But let us stay with Beckert: "This leaves us with an economic sociology that is unspecific with regard to the structural changes taking place in the organization of the economy with the development of modern capitalism. After all: All economies are embedded" (Beckert, 2007: 19, emphasis added).

In short, Beckert sides with NES's dominant trend, according to which all economies including the capitalist economy - are embedded. Contrary to most of his colleagues, however, he is aware of the ensuing problem - actually a contradiction, in my view: how is one to highlight the uniquely exceptional character of the modern capitalist market economy? The problem just does not arise within NES because the discipline acknowledges no such uniqueness: the capitalist economy is "just" another economy, with nothing to make it stand apart from other economies of the past. Once the features of the capitalist economy are ontologyzed, it may sound odd to call it a "disembedded" economy - and that is the extraordinary statement, if there is one.

We may then conclude that the concept of embeddedness

has allowed for a concentration [of NES] on meso and micro level processes of economic organization and relieved sociologists from the task of addressing socioeconomic development at the macro level. [...] We need a historical perspective if we are to understand the specific ways in which economic action is [dis]embedded in [from] institutions and social structures of modern societies. (Beckert, 2007: 19) 


\subsection{Critical assessment}

The views held by Randles (2003), Lie (1991) and Gemici (2008) seem to be good examples of the dominant positions within NES, providing us with a suitable starting point for a critical assessment of it. In The Great Transformation, according to Randles (2003: 420-421), Polanyi admits that markets can be disembedded; but in "The Economy as Instituted Process" disembeddedness is just a (theoretical) possibility, since markets are, in a way, institutionalized. Lie (1991: 219-223) tells us that the embeddedness "thesis," according to which every economic activity and institution is enmeshed in social relations and institutions, is a good theoretical basis for NES, but that Polanyi is wrong in that he does not embed the concept of market. The thesis should therefore be taken to its logical conclusion so that markets too are embedded and properly treated as social networks or organizations constituted by traders. Gemici points out that very same contradiction, and he comes to the conclusion that "All economies are embedded since economic life is a socially instituted and organized process" (2008: 9). Yet, it should also be pointed out, in order to avoid confusion, that institutionalization and embeddedness are not synonymous for Polanyi. ${ }^{11}$

Market exchange as a form of integration presents itself as an institutional pattern constituted by a system of price-making markets, but it is precisely the (autonomous) action of this institutional mechanism that causes the economy to be disembedded. Polanyi defines the economy in terms of an instituted process comprising two levels, one of which has to do with man's interaction with his natural and social surroundings, the other referring to the institutionalization of that process. Every economy, regardless of its dominant form of integration, partakes of these characteristics. It seems obvious, therefore, that Polanyi in no way denies this relationship between the human economy and the social system. What happens is that, under capitalism, all social considerations, motivations, and values take a back seat to the empirically acquired primacy of the economy, which becomes autonomous from all (conscious) social control. According to Polanyi, in a post-capitalist society - namely once the fictitious commodity nature of labor, land and money is abolished - social regulation will take the form of a democratic, participatory management of the production process, through the intervention of such institutions as the state, the trade unions, the cooperative, the factory, the township, the school, the church, etc. (Polanyi, 2000: 290-292).

\footnotetext{
${ }^{11}$ On the difference between protectionism and re-embeddedness - which is also among the most common confusions, especially in globalization-related research - see Lacher (1999: 345-346).
} 
One might then say that the economy cannot be "social" if society - meaning the people that comprise it and the institutions they create - is unable to run it, so that it is people who are controlled and have their destinies defined by it instead. Of course there is always "a connection of [...] economic exchange with some set of social structural and cultural elements in the social systems" (Barber, 1995: 400). Under capitalism, however, such connection does not take the form of interdependence but rather of the primacy of the economy over the entire social system. That is precisely why Polanyi speaks of disembeddedness with regard to this type of economy.

Let us challenge Granovetter by saying that while it is true that human action "is embedded in concrete, ongoing systems of social relations" (1985: 487), those systems are in turn framed, and largely determined by, a disembedded economy. They belong in a wider frame of reference characterized by an economy that evades human control, that is alien to humans and that overpowers them. It is not the economy that is framed by the social system, but rather the social system that is framed by the economy.

One may conclude by stating that whereas Polanyi proposes to study the place of the economy in different societies, NES claims that the place and the role of the economy are always and essentially very much the same. Just like the formalists in the field of economic anthropology, NES ends up committing the so-called "economistic fallacy," which consists of automatically and uncritically equating the economy with its market shape (Polanyi, 1968a).

\section{By way of conclusion}

The disembeddedness of the economy - i.e., its detachment from society - marked the historical rise of an automatic system of price-making markets. In every society before that, the economy had always been embedded or immersed in the social system (a statement which has nothing to do with either the desirability, the merits or the shortcomings of such societies). Therefore the "embedded" or disembedded" nature of a given economy, according to Polanyi, is closely dependent on the presence (or absence) of a system of pricemaking markets, that is, of its either being a market economy or not. Within capitalist society the economy takes on a life of its own, heedless of human will - and I believe this to be the very essence of "disembeddedness." In this sense it is easy to understand why, at least according to the meaning conferred on the concept by Polanyi, modern economies can 
never be viewed as embedded in society, because the "re-embeddedness" of the economy requires that we move beyond its current form.

By not acknowledging the unique nature of the market economy and the absolute exceptionalism of capitalism in the history of human societies, NES irretrievably moves away from the meaning originally given by Polanyi to the concept of (dis)embeddedness. As Randles rightly notes, there seems to be in NES a tendency toward

an overly fragmented (and fragmenting) secondary appropriation of Polanyi. Nowadays Polanyi's name is often used as a fashionable 'label' or convenient point of entry into an argument which thenceforth bears little resemblance, and offers little analysis-supportive, critical or otherwise- of the 'totality' of Polanyi's writing. Perhaps this is what concerns Polanyi-Levitt [Polanyi's daughter] when she refers to the potential abuse of the Polanyi legacy. (Randles, 2003: 418)

It was Polanyi's intent not just to analyze, but most of all to critique the capitalist economy and to expose its profoundly nefarious effects on both humans and nature. Any view that fails to take that critical dimension into account - selectively appropriating a concept and omitting (through ignorance?) all the rest of the author's theoretical and analytical framework, as well as how it relates to the concept - will never earn the right to claim the Polanyian legacy. That is why it is erroneous nowadays to say, in the context of NES, that "we are all Polanyians now" (Beckert, 2007: 7). This misunderstanding does no honor to Polanyi's memory.

Translated by João Paulo Moreira

Revised by Teresa Tavares

\section{References}

Barber, Bernard (1995), "All Economies Are 'Embedded': The Career of a Concept and Beyond," Social Research, 62(2), 387-413.

Beckert, Jens (2003), "Economic Sociology and Embeddedness: How Shall We Conceptualize Economic Action?" Journal of Economic Issues, 37(3), 769-787.

Beckert, Jens (2007), "The Great Transformation of Embeddedness - Karl Polanyi and the New Economic Sociology," MPIfG Discussion Paper No. 1/07, accessed on 18/04/2009, at http://www.mpifg.de/pu/mpifg dp/dp07-1.pdf.

Block, Fred (2000), "Introduction to The Great Transformation," accessed on 25/11/2010, at http://www2.dse.unibo.it/ardeni/papers_development/FredBlock_Introduction-to-Polanyi.pdf.

Block, Fred (2003), "Karl Polanyi and the Writing of The Great Transformation," Theory and Society, 32(3), 275-306.

Cumberpatch, Chris G. (2001), "Some Observations on the Concept of 'Embedded' and 'Disembedded' Economies in Archaeological Discourse," Assemblage, 6, accessed on 18/04/2009, at http://www.assemblage.group.shef.ac.uk/issue6/Cumberpatch_Econ_web.html. 
Gemici, Kurtulus (2008), "Karl Polanyi and the Antinomies of Embeddedness," Socio-Economic Review, 6, 5-33.

Ghezzi, Simone; Minzione, Enzo (2007), "Embeddedness, Path Dependency and Social Institutions: An Economic Sociology Approach," Current Sociology, 55(1), 11-23.

Graça, João Carlos (2005), "Afinal, o que é mesmo a Nova Sociologia Económica?" Revista Crítica de Ciências Sociais, 73, 111-129.

Granovetter, Mark (1985), "Economic Action and Social Structure: The Problem of Embeddedness," The American Journal of Sociology, 91(3), 481-510.

Hess, Martin (2004), "'Spatial' Relationships? Towards a Reconceptualization of Embeddedness," Progress in Human Geography, 28(2), 165-186.

Knowles, Rob (2000), "Political Economy From Below: Communitarian Anarchism as a Neglected Discourse in the Histories of Economic Thought," History of Economics Review, 31, 30-47.

Knowles, Rob; Owen, John R. (2008), "Karl Polanyi for Historians: An Alternative Economic Narrative," The European Legacy, 13(2), 175-191.

Krippner, Greta (2001), "The Elusive Market. Embeddedness and the Paradigm of Economic Sociology," Theory and Society, 30, 775-810.

Krippner, Greta et al. (2004), "Polanyi Symposium: A Conversation on Embeddedness," SocioEconomic Review, 2(1), 109-135.

Krippner, Greta; Alvarez, Anthony (2007), "Embeddedness and the Intellectual Projects of Economic Sociology," Annual Review of Sociology, 33, 219-240.

Lacher, Hannes (1999), "Embedded Liberalism, Disembedded Markets: Reconceptualising the Pax Americana," New Political Economy, 4(3), 343-360.

Lie, John (1991), "Embedding Polanyi's Market Society," Sociological Perspectives, 34(2), 219-235.

Machado, Nuno (2009), "Sociedade vs. mercado - notas sobre o pensamento económico de Karl Polanyi." Master's Thesis in Economic and Organizational Sociology. Lisboa: ISEG.

Polanyi, Karl (1957), "Aristotle Discovers the Economy," in Karl Polanyi, Conrad Arensberg \& Harry Pearson (eds.), Trade and Market in the Early Empires. Chicago: Henry Regnery, 64-94.

Polanyi, Karl (1966), Dahomey and the Slave Trade: An Analysis of an Archaic Economy. Seattle and London: University of Washington Press.

Polanyi, Karl (1968a), "The Economy as Instituted Process," in George Dalton (ed.), Primitive, Archaic and Modern Economies: Essays of Karl Polanyi. Boston: Beacon Press, 139-174.

Polanyi, Karl (1968b), "Our Obsolete Market Mentality," in George Dalton (ed.), Primitive, Archaic and Modern Economies: Essays of Karl Polanyi. Boston: Beacon Press, 59-77.

Polanyi, Karl (1977a), "The Economistic Fallacy," in Karl Polanyi \& Harry Pearson (eds.), The Livelihood of Man. New York: Academic Press, 5-17.

Polanyi, Karl (1977b), "The Economy Embedded in Society," in Karl Polanyi \& Harry Pearson (eds.), The Livelihood of Man. New York: Academic Press, 47-56.

Polanyi, Karl (1977c), "The Two Meanings of Economic," in Karl Polanyi \& Harry Pearson (eds.), The Livelihood of Man. New York: Academic Press, 19-34.

Polanyi, Karl (2001), The Great Transformation - The Political and Economic Origins of Our Time. $2^{\text {nd }}$ ed. Boston: Beacon Press. 
Polanyi, Karl; Arensberg, Conrad; Pearson, Harry (1968), "The Place of Economies in Societies," in George Dalton (ed.), Primitive, Archaic and Modern Economies: Essays of Karl Polanyi. Boston: Beacon Press, 116-138.

Polanyi-Levitt, Kari (2003), "The English Experience in the Life and Work of Karl Polanyi." Paper presented at the conference on "Polanyian Perspectives on Instituted Economic Processes, Development and Transformation," ESRC, Center for Research on Innovation and Competition, University of Manchester, 23-25 October.

Randles, Sally (2003), "Issues for a Neo-Polanyian Research Agenda in Economic Sociology," International Review of Sociology, 13(2), 409-434.

Stanfield, James R. (1986), The Economic Thought of Karl Polanyi. London: Macmillan.

Swedberg, Richard (1997), "New Economic Sociology: What Has Been Accomplished, What Is Ahead?" Acta Sociologica, 40, 161-182.

Swedberg, Richard (2004), "What has been Accomplished in New Economic Sociology and Where is it Heading?" Archives Européennes de Sociologie, 45(3), 317-330.

Swedberg, Richard (2006), "The Toolkit of Economic Sociology," SOCIUS Working Papers, No. 4/2006. 